\title{
Thermodynamic Stability of Mg-Based Laves Phases
}

\author{
Shoya Kawano ${ }^{1, * 1}$, Satoshi Iikubo ${ }^{1, * 2}$ and Hiroshi Ohtani ${ }^{2}$ \\ ${ }^{1}$ Graduate School of Life Science and Systems Engineering, Kyushu Institute of Technology, Kitakyushu 808-0196, Japan \\ ${ }^{2}$ Institute of Multidisciplinary Research for Advanced Materials, Tohoku University, Sendai 980-8577, Japan
}

To investigate the stability of various $\mathrm{Mg}$-based Laves phases, the formation enthalpy and phonon dispersion were obtained by firstprinciples calculation. The calculated formation enthalpy and phonon dispersion indicate that $\mathrm{MgX}_{2}(\mathrm{X}=\mathrm{Al}, \mathrm{Co}, \mathrm{Ni}, \mathrm{Cu}, \mathrm{Zn})$ and $\mathrm{Mg} \mathrm{X}^{\mathrm{X}}$ $(\mathrm{X}=\mathrm{Ca}, \mathrm{Sr}, \mathrm{Y}, \mathrm{Ba}, \mathrm{La})$ are stable both statically and dynamically. These results are consistent with the experimental results except for $\mathrm{MgAl}_{2}$ and $\mathrm{Mg}_{2} \mathrm{La}$. These compounds are considered to be in a metastable state in each binary system. We also used the cluster expansion method to examine the possibility of adding a third element to $\mathrm{MgZn}_{2}$. Our theoretical investigations suggest attractive interaction between $\mathrm{Zn}$ and a third element such as $\mathrm{Ag}, \mathrm{Ca}$, and $\mathrm{Zr}$ in the $\mathrm{MgZn}_{2}$ lattice. However, $\mathrm{Ca}$ and $\mathrm{Zr}$ replace a small amount of $\mathrm{Zn}$ in $\mathrm{MgZn}_{2}$ owing to the instability of $\mathrm{MgCa}_{2}$ and $\mathrm{MgZr}_{2}$, in agreement with the experimental result. Furthermore, it is suggested that $\mathrm{Zr}$ becomes stable at the $\mathrm{Mg}$ site in the $\mathrm{MgZn}_{2}$ lattice owing to the stability of $\mathrm{ZrZn}_{2}$. [doi:10.2320/matertrans.M2018079]

(Received March 5, 2018; Accepted April 9, 2018; Published May 18, 2018)

Keywords: first-principles calculations, magnesium alloy, Laves phase, precipitation, solid solution

\section{Introduction}

Mg-based alloys are expected to be applied in structural materials used in aircraft and vehicles because of their light weight and natural abundance. To date, the mechanical properties of Mg-based alloys have been improved by adding elements for imparting anticorrosion properties, grain refinement strengthening, precipitation strengthening, and so on. Despite the efforts at strengthening them, Mg-based alloys still have much lower strength than Al-based alloys; therefore, increasing their strength is important toward widespread use of Mg-based alloys. Among them, the precipitate-hardenable $\mathrm{Mg}-\mathrm{Zn}$-based alloys show relatively good mechanical properties. ${ }^{1)}$ The precipitated phase in $\mathrm{Mg}$ $\mathrm{Zn}$-based alloys is the $\mathrm{MgZn}_{2}$ Laves phase, which acts as a strengthening phase. Therefore, a promising strategy to improve the strength of $\mathrm{Mg}$-based alloys is to use the $\mathrm{MgZn}_{2}$ Laves phase effectively.

Outstanding physical properties can be obtained if a large amount of the precipitate is dispersed in the alloy; however, the low solubility of $\mathrm{Zn}$ in HCP suggests that this binary system has limitations. A promising strategy in materials design is to control the stability of the Laves phase by incorporating another element. For example, $\mathrm{Mg}-\mathrm{Zn}$-based alloys with added $\mathrm{Zr}$ are well-known commercial alloys owing to their relatively good mechanical properties. Mendis et al. reported that $\mathrm{Mg}-\mathrm{Zn}$-based alloys containing $\mathrm{Ag}$, $\mathrm{Ca}$, and $\mathrm{Zr}$ also exhibit good mechanical properties. ${ }^{2)}$ To determine the role of these additional elements, the precipitate phase has been investigated using a threedimensional atom probe; the results suggested the existence of $\mathrm{Ag}$ and $\mathrm{Ca}$ associations as well as $\mathrm{Zr}$ inclusions. ${ }^{3)}$ According to these previous studies, additional elements are distributed in the $\mathrm{MgZn}_{2}$ Laves phase and they improve the alloy strength. We seek to identify additional elements which can be used to stabilize the Laves phase. To investigate the formation mechanism of the Laves phase and the interaction

\footnotetext{
${ }^{* 1}$ Graduate Student, Kyushu Institute of Technology

${ }^{* 2}$ Corresponding author, E-mail: iikubo@life.kyutech.ac.jp
}

between $\mathrm{Mg}$ and $\mathrm{Zn}$ with additional elements in the Laves phase is useful for designing $\mathrm{Mg}-\mathrm{Zn}$-based alloys with potentially high mechanical properties.

For this purpose, first-principles calculation is suitable, because a systematic investigation of various replacement elements can be carried out more easily by this method than by experimentation. For example, Issa et al. calculated the formation enthalpy using first-principles calculation to systematically examine the stability of the precipitation phase in $\mathrm{Mg}$ alloys containing rare-earth elements. ${ }^{4}$ ) Because their calculated thermodynamic stability is consistent with that determined experimentally, first-principles calculation is also attractive for investigating the $\mathrm{Mg}-\mathrm{Zn}$-based Laves phase. Furthermore, the Gibbs energy and atomic interaction in the solid solution phase obtained by first-principles calculation were reported by our group. ${ }^{5-7)}$ These calculations can indicate the thermodynamic stability of the solid solution phase.

In this study, we investigated the stability of various binary Mg-based Laves phases. Using first-principles calculation, we systematically calculated the formation enthalpy and phonon dispersion. We also investigated the contribution of a third element added to $\mathrm{MgZn}_{2}$ using first-principles calculation combined with the cluster expansion method (CEM). On the basis of the formation enthalpy of the $\mathrm{MgZn}_{2}$ Laves phase, the formation of a metastable Laves phase and the contribution of $\mathrm{Ag}, \mathrm{Ca}$, or $\mathrm{Zr}$ to the stability of the Laves phase are discussed.

\section{Calculation Procedure}

We performed first-principles calculation based on the density functional theory (DFT) using the Vienna $a b$ initio simulation package (VASP) code. ${ }^{8,9)}$ The interaction between the ion core and the valence electrons was described by the projector-augmented wave method. ${ }^{10,11)}$ The exchange and correlation functions were given by the generalized gradient approximation, as proposed by Perdew et al. ${ }^{12,13)}$ For structural optimization and enthalpy calculation, we set the plane wave energy cutoff to $500 \mathrm{eV}$. Brillouin zone sampling 
in a primitive cell was performed by a $\Gamma$-point-centered $k$ mesh that was limited to $0.1 \AA^{-1}$, for example, a $14 \times 14 \times 8$ mesh for $\mathrm{MgZn}_{2}$. The convergence criterion for electronic self-consistency and the ionic relaxation loop were set to $10^{-6} \mathrm{eV}$ and $0.01 \mathrm{eV}$, respectively. The Methfessel-Paxton smearing method with a smearing width of $0.2 \mathrm{eV}$ and the tetrahedron method with Blöchl corrections were used for structural optimization and the enthalpy calculation, respectively. The primitive cell was fully optimized with respect to the volume and shape of the unit cell and the atomic positions. For the partially substituted system, stable crystal structures were searched for using the CEM, which was implemented using the ATAT code with first-principles calculation. ${ }^{14)}$ In the CEM, the energy of the structure is given as the sum of products of cluster correlation functions and the corresponding effective cluster interactions. The set of the cluster correlation functions for clusters can describe the crystal structure. Therefore, using energies obtained by first-principles calculations and the corresponding structures, the effective cluster interactions were obtained by inverting the CEM. Using the obtained effective cluster interactions, the energy of any crystal structure can be estimated by the CEM. Then, the stable crystal structure is predicted by firstprinciples calculations and added to the set of energies for inverting the CEM process. Repeating this procedure can rapidly predict a stable crystal structure for the substituted system. In this study, we use a four-point cluster for the maximum number of points of a cluster. The parameters of the first-principles calculations for inverting the CEM are as follows: The plane wave energy cutoff was set to $500 \mathrm{eV}$ and a $\Gamma$-point-centered $k$-mesh of 1000 points per reciprocal atom and the Methfessel-Paxton smearing method with a smearing width of $0.1 \mathrm{eV}$ were used. The convergence criterion for electronic self-consistency and the ionic relaxation loop were set to $10^{-4} \mathrm{eV}$ and $0.01 \mathrm{eV}$, respectively. This setting, $10^{-4} \mathrm{eV}$, is usually used to save on calculation time; however, this does not change the results for the stability of the solid solution.

To examine the dynamic stability of the Laves structures, we conducted a first-principles phonon calculation by the finite displacement method ${ }^{15,16)}$ using the phonopy code ${ }^{17)}$ combined with the VASP code. For this calculation, we used a $2 \times 2 \times 2$ supercell containing 96 atoms and an atomic displacement distance of $0.01 \AA$. To estimate the force due to displacements within the DFT calculation, we used a plane wave energy cutoff of $500 \mathrm{eV}$, a convergence criterion for the electronic self-consistency loop of $10^{-6} \mathrm{eV}$, a $\Gamma$-pointcentered $k$-mesh that was limited to $0.1 \AA^{-1}$, and the Methfessel-Paxton smearing method with a smearing width of $0.2 \mathrm{eV}$. In the phonon calculations, the supercell was created from the fully optimized primitive cell.

\section{Results and Discussion}

Figure 1 shows the crystal structure of the C14-type Laves phase. The space group is $P 6_{3} / \mathrm{mmc}$ (194), and the 12 atoms per primitive unit cell are located at the $2 \mathrm{a}, 4 \mathrm{f}$, and $6 \mathrm{~h}$ Wyckoff positions, $(0,0,0),(0.33333,0.66667,0.56290)$, and $(0.16970,0.33940,0.25000)$, respectively. In $\mathrm{MgZn}_{2}$, on one hand, $\mathrm{Mg}$ atoms occupy the $4 \mathrm{f}$ position, and $\mathrm{Zn}$ atoms occupy

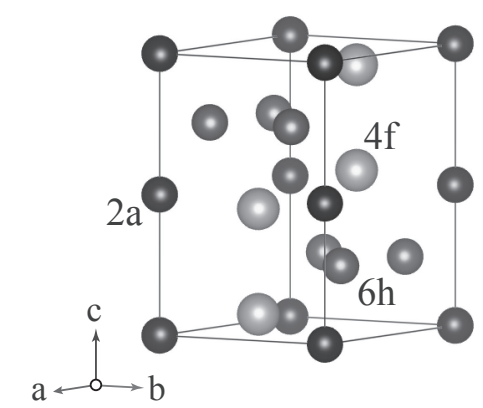

Fig. 1 Crystal structure of the Laves phase.

the $2 \mathrm{a}$ and $6 \mathrm{~h}$ positions. On the other hand, $\mathrm{Mg}$ atoms occupy the $4 \mathrm{f}$ and $6 \mathrm{~h}$ positions in $\mathrm{Mg}_{2} \mathrm{Ca}$. For these two types of Laves phases, viz., $\mathrm{MgX}_{2}$ and $\mathrm{Mg}_{2} \mathrm{X}$, static and dynamic stability are systematically investigated by first-principles calculations for $\mathrm{X}=\mathrm{Al}, \mathrm{Si}, \mathrm{Ca}, \mathrm{Sc}, \mathrm{Ti}, \mathrm{V}, \mathrm{Cr}, \mathrm{Mn}, \mathrm{Fe}, \mathrm{Co}, \mathrm{Ni}$, $\mathrm{Cu}, \mathrm{Zn}, \mathrm{Ga}, \mathrm{Ge}, \mathrm{Sr}, \mathrm{Y}, \mathrm{Zr}, \mathrm{Ag}$, In, Sn, Sb, Ba, La, Ce, Pr, Nd, $\mathrm{Pm}, \mathrm{Sm}, \mathrm{Eu}, \mathrm{Gd}, \mathrm{Tb}, \mathrm{Dy}, \mathrm{Ho}, \mathrm{Er}, \mathrm{Tm}, \mathrm{Yb}$, and $\mathrm{Lu}$, which are mainly fourth-period and rare-earth elements.

Figure 2(a) and (b) show the calculated lattice constants of $\mathrm{MgX}_{2}$ and $\mathrm{Mg}_{2} \mathrm{X}$, respectively, compared with the available experimental data. ${ }^{18)}$ The calculated lattice constants of $\mathrm{MgX}_{2}$ $(\mathrm{X}=\mathrm{Co}, \mathrm{Zn})$ and $\mathrm{Mg}_{2} \mathrm{X}(\mathrm{X}=\mathrm{Ca}, \mathrm{Sr}, \mathrm{Y}, \mathrm{Ba}, \mathrm{Tb}, \mathrm{Dy}, \mathrm{Ho}, \mathrm{Er}$, $\mathrm{Tm}, \mathrm{Yb}, \mathrm{Lu})$ are consistent with those experimentally determined within $0.1 \AA$. Therefore, the optimized structures are reliable for estimating the formation enthalpy.

To investigate the stability of the Laves phase, we calculated the formation enthalpy $H$, which is given by,

$$
H\left(A_{x} B_{y}\right)=E_{\text {total }}\left(A_{x} B_{y}\right)-\frac{x E_{\text {pure }}(A)+y E_{\text {pure }}(B)}{x+y}
$$

where, $E_{\text {total }}\left(\mathrm{A}_{x} \mathrm{~B}_{y}\right), E_{\text {pure }}(\mathrm{A})$, and $E_{\text {pure }}(\mathrm{B})$ are the total energies of an atom for the compound $\mathrm{A}_{x} \mathrm{~B}_{y}$, pure state $\mathrm{A}$, and pure state B, respectively. Figure 3(a) and (b) show the calculated formation enthalpy, $H$ of various optimized Laves phases. A negative formation enthalpy implies that the Laves phase is statically stable at $0 \mathrm{~K}$. Hence, the statically stable elements for $\mathrm{MgX}_{2}$ are $\mathrm{X}=\mathrm{Al}, \mathrm{Co}, \mathrm{Ni}, \mathrm{Cu}, \mathrm{Zn}, \mathrm{Ga}$, and $\mathrm{Ag}$, and those for $\mathrm{Mg}_{2} \mathrm{X}$ are $\mathrm{X}=\mathrm{Ca}, \mathrm{Sr}, \mathrm{Y}, \mathrm{Ba}, \mathrm{La}, \mathrm{Pr}, \mathrm{Nd}, \mathrm{Pm}$, $\mathrm{Sm}, \mathrm{Eu}, \mathrm{Gd}, \mathrm{Tb}, \mathrm{Dy}, \mathrm{Ho}, \mathrm{Er}, \mathrm{Tm}, \mathrm{Yb}$, and Lu. In contrast, the other compounds show a positive formation enthalpy, implying that those elements have a statically unstable Laves phase.

The dynamical stability of the Laves phase was also examined by calculating the phonon dispersion of $\mathrm{MgX}_{2}$ $\left(\mathrm{X}=\mathrm{Al}, \mathrm{Co}, \mathrm{Ni}, \mathrm{Cu}, \mathrm{Zn}, \mathrm{Ga}, \mathrm{Ag}\right.$ ) and $\mathrm{Mg}_{2} \mathrm{X}(\mathrm{X}=\mathrm{Ca}, \mathrm{Sr}, \mathrm{Y}$, $\mathrm{Ba}, \mathrm{La})$. Figure 4 shows the phonon dispersion and partial DOS of $\mathrm{MgX}_{2}(\mathrm{X}=\mathrm{Al}, \mathrm{Co}, \mathrm{Ni}, \mathrm{Cu}, \mathrm{Zn}, \mathrm{Ga}, \mathrm{Ag})$ and $\mathrm{Mg}_{2} \mathrm{X}$ $(\mathrm{X}=\mathrm{Ca}, \mathrm{Sr}, \mathrm{Y}, \mathrm{Ba}, \mathrm{La})$. The vertical axis represents the frequency, and the horizontal axis represents the wave vector for the phonon dispersion and the partial DOS, respectively. The partial DOS shows the vibrational contributions of $\mathrm{Mg}$ and $\mathrm{X}$ atoms. The wave vectors of the phonon dispersion are shown along the high-symmetry direction, A-H-L-A- $\Gamma$ $\mathrm{K}-\mathrm{M}-\Gamma$. In all, there are 36 phonon branches for $\mathrm{MgX}_{2}$ and $\mathrm{Mg}_{2} \mathrm{X}$. For $\mathrm{MgAl}_{2}$, the contribution of $\mathrm{Mg}$ and $\mathrm{Al}$ extends over a broad range of energy. As X elements become heavier, the higher frequency is mainly contributed by $\mathrm{Mg}$, and the 


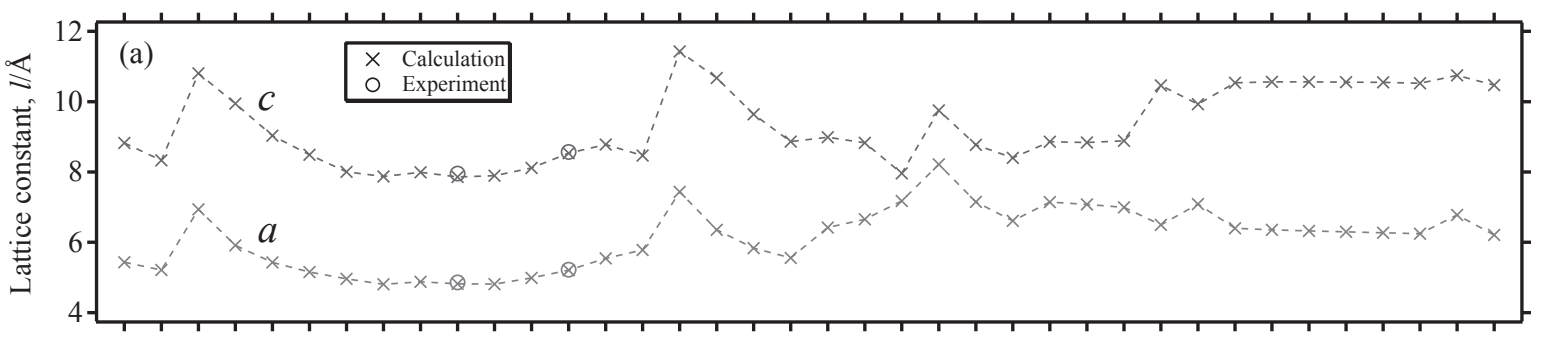

Al Si Ca Sc Ti V CrMnFe Co NiCuZn GaGe Sr Y Zr Ag In Sn Sb Ba La Ce Pr NdPmSmEu GdTbDyHo ErTmYbLu

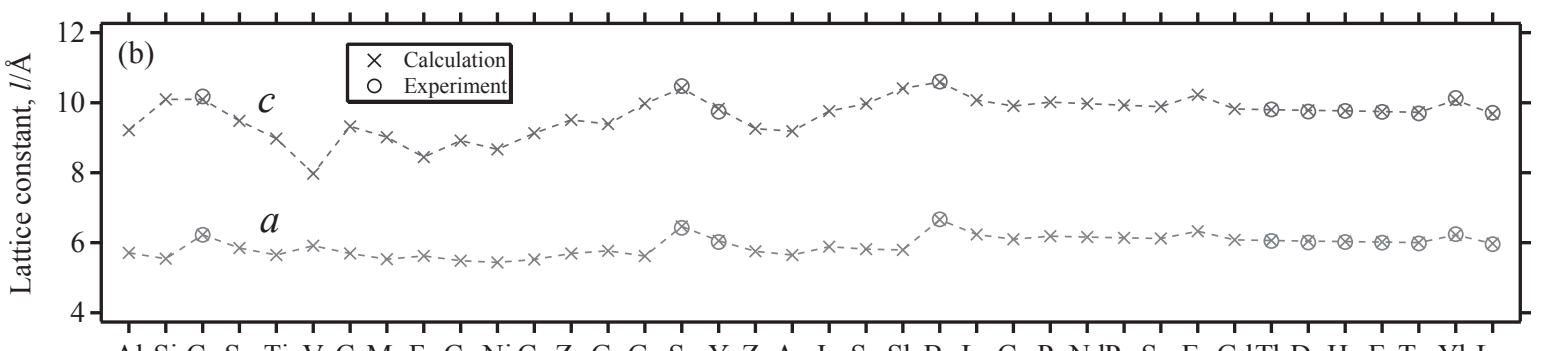

Al Si Ca Sc Ti V CrMnFe Co Ni CuZnGaGe Sr Y Zr Ag In Sn Sb Ba La Ce Pr NdPmSmEuGdTbDyHo ErTmYbLu

Fig. 2 Calculated lattice constants of (a) $\mathrm{MgX}_{2}$ and (b) $\mathrm{Mg}_{2} \mathrm{X}$ compared with the available experimental data.
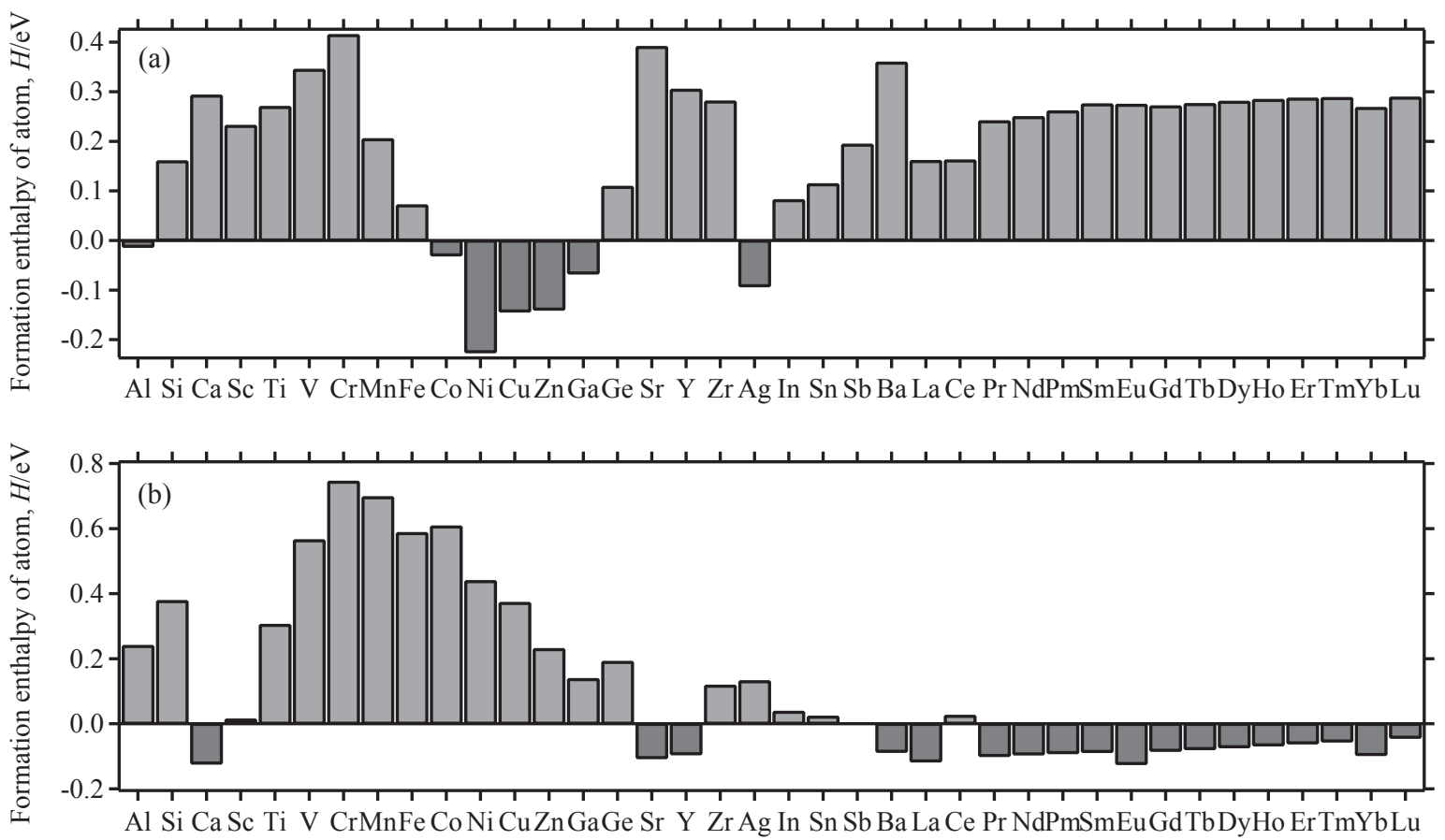

Fig. 3 The calculated formation enthalpy of (a) $\mathrm{MgX}_{2}$ and (b) $\mathrm{Mg}_{2} \mathrm{X}$.

lower frequency by $\mathrm{X}$ elements, as shown in the partial DOS. In particular, phonon branches distinctly separate into high- and low-energy parts for $\mathrm{Mg}_{2} \mathrm{Sr}, \mathrm{Mg}_{2} \mathrm{Y}, \mathrm{Mg}_{2} \mathrm{Ba}$, and $\mathrm{Mg}_{2} \mathrm{La}$.

In the phonon dispersion, an imaginary value of the frequency indicates that the structure is dynamically unstable. Therefore, the dynamically stable compounds are $\mathrm{MgX}_{2}$ $(\mathrm{X}=\mathrm{Al}, \mathrm{Co}, \mathrm{Ni}, \mathrm{Cu}, \mathrm{Zn})$ and $\mathrm{Mg}_{2} \mathrm{X}(\mathrm{X}=\mathrm{Ca}, \mathrm{Sr}, \mathrm{Y}, \mathrm{Ba}$, $\mathrm{La}$ ), because no negative frequencies appear. In contrast, $\mathrm{MgGa}_{2}$ and $\mathrm{MgAg}_{2}$, which show some negative frequencies, are dynamically unstable compounds. These modes are assigned to $\mathrm{A}_{2 \mathrm{~g}}$ and $\mathrm{B}_{2 \mathrm{u}}$ for $\mathrm{MgGa}_{2}$ and $\mathrm{A}_{2 \mathrm{~g}}, \mathrm{~B}_{2 \mathrm{u}}$, and $\mathrm{E}_{2 \mathrm{u}}$ for $\mathrm{MgAg}_{2}$. Therefore, $\mathrm{MgGa}_{2}$ and $\mathrm{MgAg}_{2}$ exhibit a more stable structure. The calculated formation enthalpy and phonon dispersion suggest that the compounds that are both statically and dynamically stable are $\operatorname{MgX}_{2}(\mathrm{X}=\mathrm{Al}$, $\mathrm{Co}, \mathrm{Ni}, \mathrm{Cu}, \mathrm{Zn})$ and $\mathrm{Mg}_{2} \mathrm{X}(\mathrm{X}=\mathrm{Ca}, \mathrm{Sr}, \mathrm{Y}, \mathrm{Ba}, \mathrm{La})$.

Figure 5 shows the temperature dependence of the harmonic phonon energy, entropy, and Helmholtz free energy of the Laves phase for $\mathrm{MgX}_{2}(\mathrm{X}=\mathrm{Al}, \mathrm{Co}, \mathrm{Cu}, \mathrm{Ni}$, and $\mathrm{Zn})$ and $\mathrm{Mg}_{2} \mathrm{X}(\mathrm{X}=\mathrm{Ba}, \mathrm{Ca}, \mathrm{La}, \mathrm{Sr}, \mathrm{Y})$. The entropy term shows a larger material dependence than the harmonic phonon energy. This behavior can be understood by the phonon dispersion relation and DOS, as shown in Fig. 4. The entropy increases with the increasing number of phonons excited at a temperature. The phonon frequency of the Laves phase decreases with increasingly heavy elements, thereby increasing the number of phonons.

Here, we compare these calculated results with the experimental phase stabilities, and these are listed in 

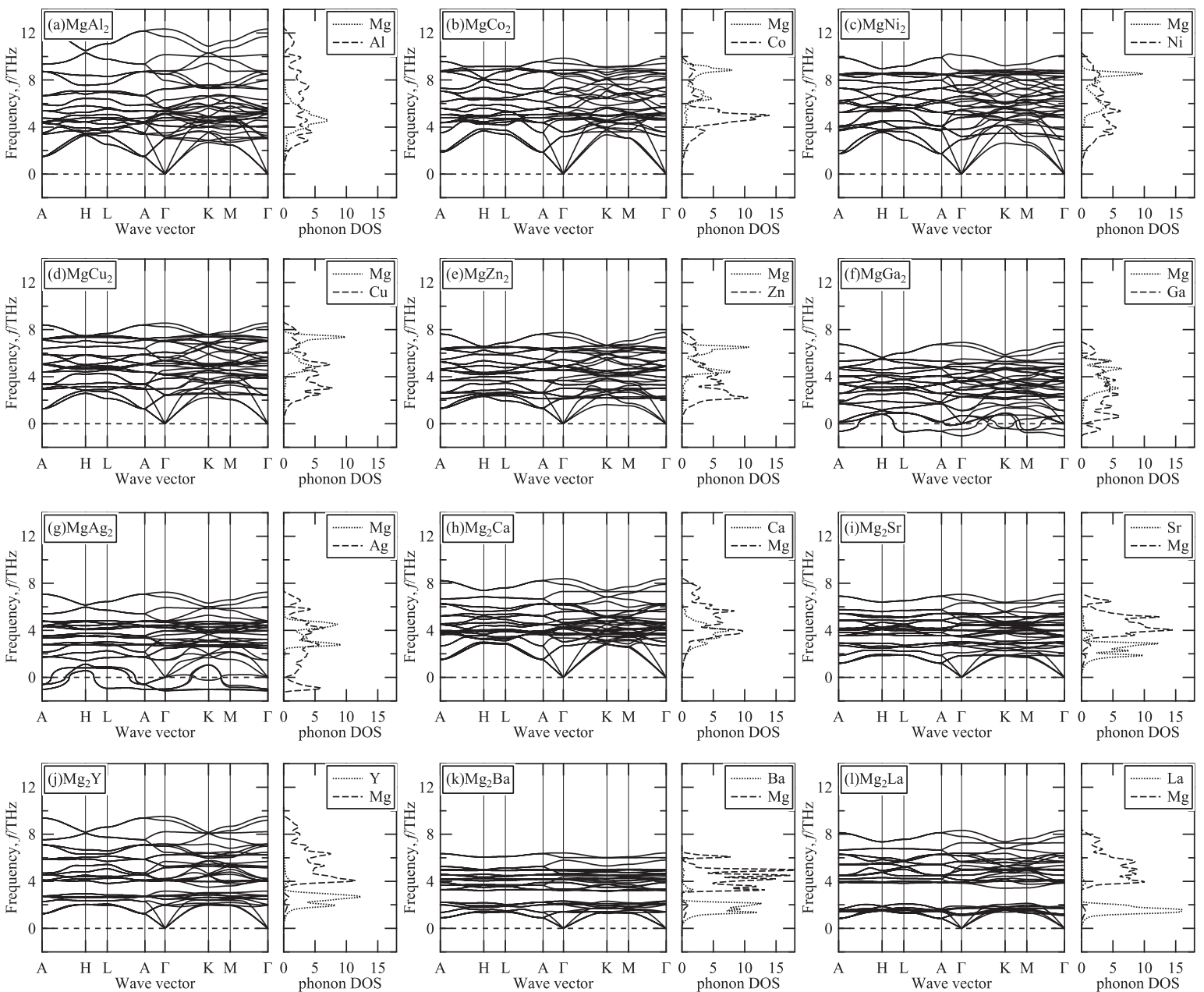

Fig. 4 The calculated phonon dispersion and partial DOS of $\mathrm{MgX}_{2}$ for $\mathrm{X}=$ (a) $\mathrm{Al}$, (b) $\mathrm{Co}$, (c) $\mathrm{Ni}$, (d) $\mathrm{Cu}$, (e) $\mathrm{Zn}$, (f) $\mathrm{Ga}$, (g) $\mathrm{Ag}$, and $\mathrm{Mg}_{2} \mathrm{X}$ for $\mathrm{X}=$ (h) $\mathrm{Ca}$, (i) Sr, (j) Y, (k) Ba, and (l) La.
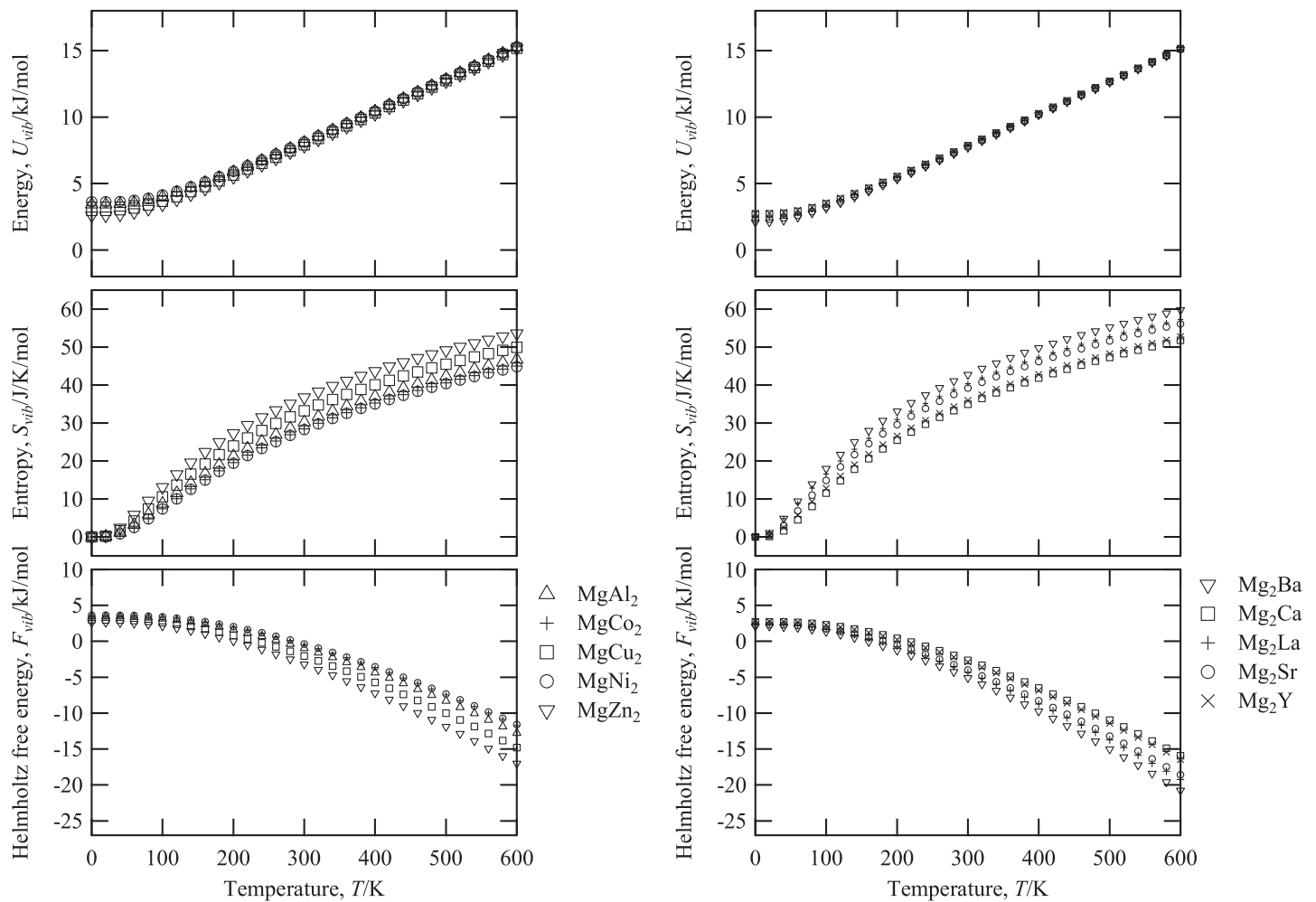

Fig. 5 Temperature dependence of the harmonic phonon energy, entropy, and Helmholtz free energy of the Laves phase for MgX 2 $(\mathrm{X}=\mathrm{Al}, \mathrm{Co}, \mathrm{Cu}, \mathrm{Ni}$, and $\mathrm{Zn})$ and $\mathrm{Mg}_{2} \mathrm{X}(\mathrm{X}=\mathrm{Ba}, \mathrm{Ca}, \mathrm{La}, \mathrm{Sr}, \mathrm{Y})$. 
Table 1 Comparison between the calculated stability of the Laves structure and the most stable phases of $\mathrm{MgX}_{2}$ and $\mathrm{Mg}_{2} \mathrm{X}$ at room temperature, which were evaluated from phase diagrams.

\begin{tabular}{|c|c|c|c|c|c|c|}
\hline \multirow[b]{2}{*}{$\mathrm{X}$} & \multicolumn{3}{|c|}{$\mathrm{MgX}_{2}$} & \multicolumn{3}{|c|}{$\mathrm{Mg}_{2} \mathrm{X}$} \\
\hline & Calculation & Stable Phase & Prototype & Calculation & Stable Phase & Prototype \\
\hline $\mathrm{Al}$ & stable & $\underline{\mathrm{Al}+\mathrm{Mg}_{28} \mathrm{Al}_{45}}$ & $\mathrm{Cu}+\mathrm{Mg}_{28} \mathrm{Al}_{45}$ & unstable & $\mathrm{Mg}+\mathrm{Mg}_{17} \mathrm{Al}_{12}$ & $\mathrm{Mg}+\mathrm{Mg}_{17} \mathrm{Al}_{12}$ \\
\hline $\mathrm{Si}$ & unstable & $\mathrm{Si}+\mathrm{Mg}_{2} \mathrm{Si}$ & $\mathrm{C}+\mathrm{CaF}_{2}$ & unstable & $\mathrm{Mg}_{2} \mathrm{Si}$ & $\mathrm{CaF}_{2}$ \\
\hline $\mathrm{Ca}$ & unstable & $\mathrm{Ca}+\mathrm{Mg}_{2} \mathrm{Ca}$ & $\mathrm{Cu}+\mathrm{MgZn}_{2}$ & stable & $\mathrm{Mg}_{2} \mathrm{Ca}$ & $\mathrm{MgZn}_{2}$ \\
\hline $\mathrm{Sc}$ & unstable & $\mathrm{Sc}+\mathrm{MgSc}$ & $\mathrm{Mg}+\mathrm{CsCl}$ & unstable & $\mathrm{MgSc}$ & $\mathrm{CsCl}$ \\
\hline $\mathrm{Ti}$ & unstable & $\mathrm{Mg}+\mathrm{Ti}$ & $\mathrm{Mg}+\mathrm{Mg}$ & unstable & $\mathrm{Mg}+\mathrm{Ti}$ & $\mathrm{Mg}+\mathrm{Mg}$ \\
\hline $\mathrm{V}$ & unstable & $\mathrm{Mg}+\mathrm{V}$ & $\mathrm{Mg}+\mathrm{W}$ & unstable & $\mathrm{Mg}+\mathrm{V}$ & $\mathrm{Mg}+\mathrm{W}$ \\
\hline $\mathrm{Cr}$ & unstable & - & - & unstable & - & - \\
\hline $\mathrm{Mn}$ & unstable & $\mathrm{Mg}+\mathrm{Mn}$ & $\mathrm{Mg}+\mathrm{Mn}$ & unstable & $\mathrm{Mg}+\mathrm{Mn}$ & $\mathrm{Mg}+\mathrm{Mn}$ \\
\hline $\mathrm{Fe}$ & unstable & $\mathrm{Mg}+\mathrm{Fe}$ & $\mathrm{Mg}+\mathrm{W}$ & unstable & $\mathrm{Mg}+\mathrm{Fe}$ & $\mathrm{Mg}+\mathrm{W}$ \\
\hline $\mathrm{Co}$ & stable & $\mathrm{MgCo}_{2}$ & $\mathrm{MgZn}_{2}$ & unstable & $\mathrm{Mg}+\mathrm{MgCo}_{2}$ & $\mathrm{Mg}+\mathrm{MgZn}_{2}$ \\
\hline $\mathrm{Ni}$ & stable & $\mathrm{MgNi}_{2}$ & $\mathrm{MgNi}_{2}$ & unstable & $\mathrm{Mg}_{2} \mathrm{Ni}$ & $\mathrm{Mg}_{2} \mathrm{Ni}$ \\
\hline $\mathrm{Cu}$ & stable & $\mathrm{MgCu}_{2}$ & $\mathrm{MgCu}_{2}$ & unstable & $\mathrm{Mg}_{2} \mathrm{Cu}$ & $\mathrm{Mg}_{2} \mathrm{Cu}$ \\
\hline $\mathrm{Zn}$ & stable & $\mathrm{MgZn}_{2}$ & $\mathrm{MgZn}_{2}$ & unstable & $\mathrm{Mg}+\mathrm{Mg}_{21} \mathrm{Zn}_{25}$ & $\mathrm{Mg}+\mathrm{Zr}_{21} \operatorname{Re}_{25}$ \\
\hline $\mathrm{Ga}$ & unstable & $\mathrm{MgGa}_{2}$ & $\mathrm{MgGa}_{2}$ & unstable & $\mathrm{Mg}_{2} \mathrm{Ga}$ & $\mathrm{Mg}_{2} \mathrm{Ga}$ \\
\hline $\mathrm{Ge}$ & unstable & $\mathrm{Ge}+\mathrm{Mg}_{2} \mathrm{Ge}$ & $\mathrm{C}+\mathrm{CaF}_{2}$ & unstable & $\mathrm{Mg}_{2} \mathrm{Ge}$ & $\mathrm{CaF}_{2}$ \\
\hline $\mathrm{Sr}$ & unstable & $\mathrm{Sr}+\mathrm{SrMg}_{2}$ & $\mathrm{Sr}+\mathrm{MgZn}_{2}$ & stable & $\mathrm{Mg}_{2} \mathrm{Sr}$ & $\mathrm{MgZn}_{2}$ \\
\hline $\mathrm{Y}$ & unstable & $\mathrm{Y}+\mathrm{MgY}$ & $\mathrm{Mg}+\mathrm{CsCl}$ & stable & $\mathrm{Mg}_{2} \mathrm{Y}$ & $\mathrm{MgZn}_{2}$ \\
\hline $\mathrm{Zr}$ & unstable & $\mathrm{Mg}+\mathrm{Zr}$ & $\mathrm{Mg}+\mathrm{Mg}$ & unstable & $\mathrm{Mg}+\mathrm{Zr}$ & $\mathrm{Mg}+\mathrm{Mg}$ \\
\hline $\mathrm{Ag}$ & unstable & $\mathrm{MgAg}_{3}+\mathrm{MgAg}$ & $\mathrm{Cu}_{3} \mathrm{Au}+\mathrm{CsCl}$ & unstable & $\mathrm{MgAg}+\mathrm{Mg}_{25} \mathrm{Ag}_{8}$ & $\mathrm{CsCl}+\mathrm{Mg}_{26} \mathrm{Ag}_{7}$ \\
\hline In & unstable & $\mathrm{Mg}_{1.2} \mathrm{In}_{2.8}+\mathrm{MgIn}$ & $\mathrm{Cu}_{3} \mathrm{Au}+\mathrm{CuAu}$ & unstable & $\mathrm{Mg}_{2}$ In & $\mathrm{Mg}_{2} \mathrm{In}$ \\
\hline Sn & unstable & $\mathrm{Mg}_{2} \mathrm{Sn}+\mathrm{L}(\mathrm{Sn})$ & $\mathrm{CaF}_{2}+\mathrm{L}(\mathrm{Sn})$ & unstable & $\mathrm{Mg}_{2} \mathrm{Sn}$ & $\mathrm{CaF}_{2}$ \\
\hline $\mathrm{Sb}$ & unstable & $\mathrm{Sb}+\mathrm{Mg}_{3} \mathrm{Sb}_{2}$ & $\mathrm{As}+\mathrm{La}_{2} \mathrm{O}_{3}$ & unstable & $\mathrm{Mg}+\mathrm{Mg}_{3} \mathrm{Sb}_{2}$ & $\mathrm{Mg}+\mathrm{La}_{2} \mathrm{O}_{3}$ \\
\hline $\mathrm{Ba}$ & unstable & $\mathrm{Ba}+\mathrm{BaMg}_{2}$ & $\mathrm{~W}+\mathrm{MgZn}_{2}$ & stable & $\mathrm{BaMg}_{2}$ & $\mathrm{MgZn}_{2}$ \\
\hline $\mathrm{La}$ & unstable & $\mathrm{La}+\mathrm{MgLa}$ & $\mathrm{Nd}+\mathrm{CsCl}$ & stable & $\underline{\mathrm{MgLa}+\mathrm{Mg}_{3} \mathrm{La}}$ & $\mathrm{CsCl}+\mathrm{BiF}_{3}$ \\
\hline $\mathrm{Ce}$ & unstable & $\mathrm{Ce}+\mathrm{MgCe}$ & $\mathrm{Cu}+\mathrm{CsCl}$ & unstable & $\mathrm{MgCe}+\mathrm{Mg}_{3} \mathrm{Ce}$ & $\mathrm{CsCl}+\mathrm{BiF}_{3}$ \\
\hline $\operatorname{Pr}$ & unstable & $\mathrm{Pr}+\mathrm{MgPr}$ & $\mathrm{Nd}+\mathrm{CsCl}$ & unstable & $\mathrm{MgPr}+\mathrm{Mg}_{3} \mathrm{Pr}$ & $\mathrm{CsCl}+\mathrm{BiF}_{3}$ \\
\hline $\mathrm{Nd}$ & unstable & $\mathrm{Nd}+\mathrm{MgNd}$ & $\mathrm{Nd}+\mathrm{CsCl}$ & unstable & $\mathrm{MgNd}+\mathrm{Mg}_{3} \mathrm{Nd}$ & $\mathrm{CsCl}+\mathrm{BiF}_{3}$ \\
\hline Pm & unstable & - & - & unstable & - & - \\
\hline Sm & unstable & $\mathrm{Sm}+\mathrm{MgSm}$ & $\mathrm{Sm}+\mathrm{CsCl}$ & unstable & $\mathrm{Mg}_{2} \mathrm{Sm}$ & $\mathrm{MgCu}_{2}$ \\
\hline $\mathrm{Eu}$ & unstable & $\mathrm{Eu}+\mathrm{MgEu}$ & $\mathrm{W}+\mathrm{CsCl}$ & unstable & $\mathrm{Mg}_{2} \mathrm{Eu}$ & $\mathrm{MgZn}_{2}$ \\
\hline Gd & unstable & $\mathrm{Gd}+\mathrm{MgGd}$ & $\mathrm{Mg}+\mathrm{CsCl}$ & unstable & $\mathrm{Mg}_{2} \mathrm{Gd}$ & $\mathrm{MgCu}_{2}$ \\
\hline $\mathrm{Tb}$ & unstable & $\mathrm{Tb}+\mathrm{MgGd}$ & $\mathrm{Mg}+\mathrm{CsCl}$ & unstable & $\mathrm{Mg}_{2} \mathrm{~Tb}$ & $\mathrm{MgZn}_{2}$ \\
\hline Dy & unstable & $\mathrm{Dy}+\mathrm{MgGd}$ & $\mathrm{Mg}+\mathrm{CsCl}$ & unstable & $\mathrm{Mg}_{2} \mathrm{Dy}$ & $\mathrm{MgZn}_{2}$ \\
\hline Ho & unstable & $\mathrm{Ho}+\mathrm{MgGd}$ & $\mathrm{Mg}+\mathrm{CsCl}$ & unstable & $\mathrm{Mg}_{2} \mathrm{Ho}$ & $\mathrm{MgZn}_{2}$ \\
\hline Er & unstable & $\mathrm{Er}+\mathrm{MgGd}$ & $\mathrm{Mg}+\mathrm{CsCl}$ & unstable & $\mathrm{Mg}_{2} \mathrm{Er}$ & $\mathrm{MgZn}_{2}$ \\
\hline $\mathrm{Tm}$ & unstable & $\mathrm{Tm}+\mathrm{MgGd}$ & $\mathrm{Mg}+\mathrm{CsCl}$ & unstable & $\mathrm{Mg}_{2} \mathrm{Tm}$ & $\mathrm{MgZn}_{2}$ \\
\hline $\mathrm{Yb}$ & unstable & $\mathrm{Yb}+\mathrm{Mg}_{2} \mathrm{Yb}$ & $\mathrm{Cu}+\mathrm{MgZn}_{2}$ & unstable & $\mathrm{Mg}_{2} \mathrm{Yb}$ & $\mathrm{MgZn}_{2}$ \\
\hline $\mathrm{Lu}$ & unstable & $\mathrm{Lu}+\mathrm{MgGd}$ & $\mathrm{Mg}+\mathrm{CsCl}$ & unstable & $\mathrm{Mg}_{2} \mathrm{Lu}$ & $\mathrm{MgZn}_{2}$ \\
\hline
\end{tabular}

Table 1. The most stable phases of $\mathrm{MgX}_{2}$ and $\mathrm{Mg}_{2} \mathrm{X}$ at room temperature were determined from the phase diagrams. ${ }^{19-21)}$ Note that the Laves phase has three crystal structures. Close relationships between these three structures, which consist of stacks of six fundamental layers, was found by Berry and Raynor $^{22)}$ and Komura. ${ }^{23)}$ They found that C14 (prototype: $\mathrm{MgZn}_{2}$ ) consists of $\mathrm{AB}^{\prime}$ stacking layers, $\mathrm{C} 15$ (prototype: $\left.\mathrm{MgCu}_{2}\right)$ consists of $\mathrm{ABC}$ stacking layers, and $\mathrm{C} 36$ (prototype: $\mathrm{MgNi}_{2}$ ) consists of $\mathrm{AB}^{\prime} \mathrm{A}^{\prime}$ stacking layers in the topologically close-packed structure. Because of their close topological relationship, the C14-, C15-, and C36-type Laves phases were treated as the same Laves structure in this study.
Table 1 shows that the calculated stable compounds are $\mathrm{MgX}_{2}(\mathrm{X}=\mathrm{Al}, \mathrm{Co}, \mathrm{Ni}, \mathrm{Cu}, \mathrm{Zn})$ and $\mathrm{Mg}_{2} \mathrm{X}(\mathrm{X}=\mathrm{Ca}, \mathrm{Sr}, \mathrm{Y}$, $\mathrm{Ba}, \mathrm{La}) . \mathrm{MgX}_{2}$ with $\mathrm{X}=\mathrm{Co}, \mathrm{Ni}, \mathrm{Cu}$, and $\mathrm{Zn}$ and $\mathrm{Mg}_{2} \mathrm{X}$ with $\mathrm{X}=\mathrm{Ca}, \mathrm{Sr}, \mathrm{Y}$, and $\mathrm{Ba}$ are experimentally observed as the Laves phase; therefore, the calculated results are consistent with the experimental ones. In contrast, the calculated stable structure is inconsistent for $\mathrm{MgAl}_{2}$ and $\mathrm{Mg}_{2} \mathrm{La}$, because the mixtures $\mathrm{Al}+\mathrm{Mg}_{28} \mathrm{Al}_{45}$ and $\mathrm{MgLa}+\mathrm{Mg}_{3} \mathrm{La}$ are stable for the $\mathrm{Mg}-\mathrm{Al}$ and $\mathrm{Mg}-\mathrm{La}$ binary systems, respectively. Our calculated results indicate that $\mathrm{MgAl}_{2}$ and $\mathrm{Mg}_{2} \mathrm{La}$ are stable compounds, but experiments indicate that $\mathrm{MgAl}_{2}$ and $\mathrm{Mg}_{2} \mathrm{La}$ are not observed to be stable compounds. In the $\mathrm{Mg}-\mathrm{Al}$ system, $\mathrm{Mg}_{1.2} \mathrm{Al}_{1.8}$ in the C14-type Laves phase has been 

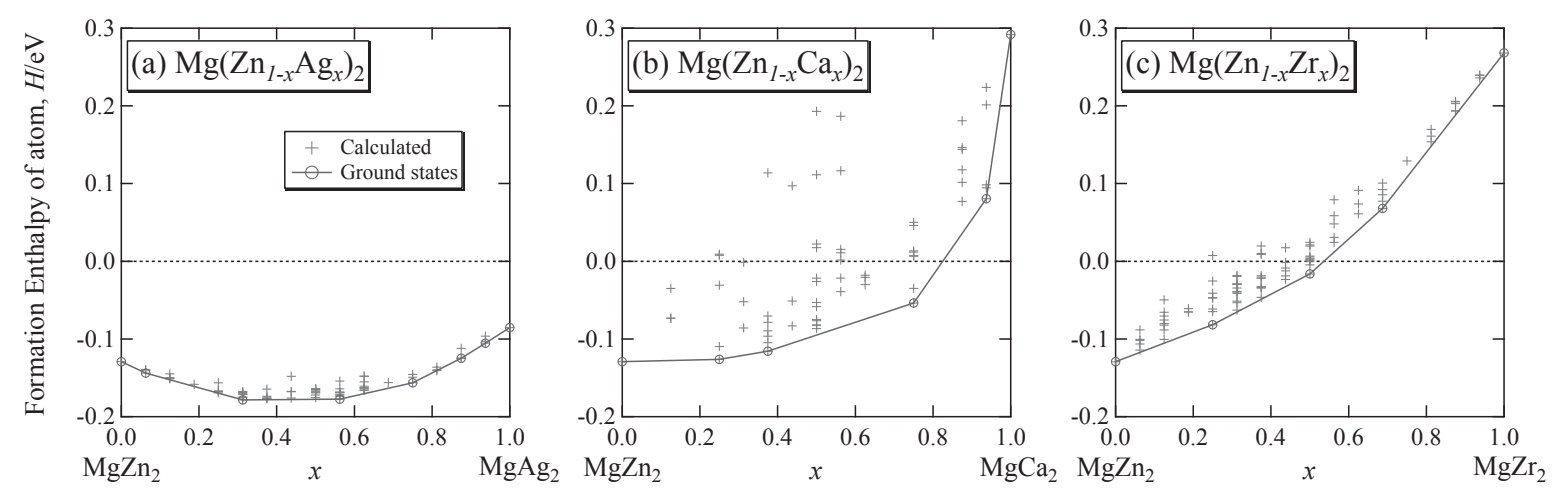

Fig. 6 Calculated formation enthalpies of (a) $\operatorname{Mg}\left(\mathrm{Zn}_{1-x} \mathrm{Ag}_{x}\right)_{2}$, (b) $\mathrm{Mg}\left(\mathrm{Zn}_{1-x} \mathrm{Ca}_{x}\right)_{2}$, and (c) $\operatorname{Mg}\left(\mathrm{Zn}_{1-x} \mathrm{Zr}_{x}\right)_{2}$.

observed using a rapid cooling technique. ${ }^{24)}$ In the $\mathrm{Mg}-\mathrm{La}$ system, $\mathrm{Mg}_{2} \mathrm{La}$ in the C15-type Laves phase is the most stable phase at 620 to $769^{\circ} \mathrm{C} .^{25)}$ These experiments and our results suggest that $\mathrm{MgAl}_{2}$ and $\mathrm{Mg}_{2} \mathrm{La}$ are metastable compounds. Furthermore, the calculated result shows that the statically unstable compounds are $\mathrm{MgX}_{2}$ with $\mathrm{X}=\mathrm{Si}, \mathrm{Ca}, \mathrm{Sc}$, Ti, V, Cr, Mn, Fe, Ge, Sr, Y, Zr, In, Sn, Sb, Ba, La, Ce, Pr, $\mathrm{Nd}, \mathrm{Pm}, \mathrm{Sm}, \mathrm{Eu}, \mathrm{Gd}, \mathrm{Tb}, \mathrm{Dy}, \mathrm{Ho}, \mathrm{Er}, \mathrm{Tm}, \mathrm{Yb}$, and $\mathrm{Lu}$, and $\mathrm{Mg}_{2} \mathrm{X}$ with $\mathrm{X}=\mathrm{Al}, \mathrm{Si}, \mathrm{Sc}, \mathrm{Ti}, \mathrm{V}, \mathrm{Cr}, \mathrm{Mn}, \mathrm{Fe}, \mathrm{Co}, \mathrm{Ni}, \mathrm{Cu}, \mathrm{Zn}$, $\mathrm{Ga}, \mathrm{Ge}, \mathrm{Zr}, \mathrm{Ag}, \mathrm{In}, \mathrm{Sn}, \mathrm{Sb}$, and $\mathrm{Ce}$, and the dynamically unstable compounds are $\mathrm{MgX}_{2}$ with $\mathrm{X}=\mathrm{Ga}$ and $\mathrm{Ag}$. These results are also consistent with the experimental stabilities.

Next, using the CEM, we examined the possibility of adding a third element to the Laves phase, $\mathrm{Mg}-\mathrm{Zn}-\mathrm{X}(\mathrm{X}=$ $\mathrm{Ag}, \mathrm{Ca}, \mathrm{Zr}$ ), because these systems have been investigated experimentally. 2,3,26-29) For example, on one hand, Wang et al. reported that $\mathrm{Ag}$ is located at the $2 \mathrm{a}$ and $6 \mathrm{~h}$ sites, resulting in the formation of $\mathrm{Mg}(\mathrm{Ag}, \mathrm{Zn})_{2} \cdot{ }^{26)}$ On the other hand, as Zhang et al. reported, a small amount of $\mathrm{Ca}$ is introduced into the $\mathrm{MgZn}_{2}$ phase; instead, $\mathrm{Ca}$ forms $\mathrm{Mg}_{2} \mathrm{Ca}$ separately. ${ }^{28)}$ Bhattacharjee et al. reported that $\mathrm{Zr}$ is located at the $6 \mathrm{~h}$ and $2 \mathrm{a}$ sites and forms $\mathrm{Mg}(\mathrm{Zn}, \mathrm{Zr})_{2} .{ }^{27)}$ Therefore, to study the ability to form the solid solution phase, we calculated the formation enthalpies of $\mathrm{Mg}\left(\mathrm{Zn}_{1-x} \mathrm{Ag}_{x}\right)_{2}$, $\operatorname{Mg}\left(\mathrm{Zn}_{1-x} \mathrm{Ca}_{x}\right)_{2}$, and $\mathrm{Mg}\left(\mathrm{Zn}_{1-x} \mathrm{Zr}_{x}\right)_{2}$.

Figure 6 shows the calculated formation enthalpies of (a) $\operatorname{Mg}\left(\mathrm{Zn}_{1-x} \mathrm{Ag}_{x}\right)_{2}$, (b) $\operatorname{Mg}\left(\mathrm{Zn}_{1-x} \mathrm{Ca}_{x}\right)_{2}$, and (c) $\operatorname{Mg}\left(\mathrm{Zn}_{1-x} \mathrm{Zr}_{x}\right)_{2}$. The crosses represent the formation enthalpies calculated using the first-principles technique, and the circles and solid lines represent the ground states of these enthalpies. As shown in Fig. 6(a), the formation enthalpy of $\mathrm{Mg}\left(\mathrm{Zn}_{1-x} \mathrm{Ag}_{x}\right)_{2}$ decreases with increasing $\mathrm{Ag}$ content in the range of $0<$ $x<0.3$ and has the minimum value at $\sim 0.5$. The interaction between $\mathrm{Zn}$ and $\mathrm{Ag}$ in $\operatorname{Mg}\left(\mathrm{Zn}_{1-x} \mathrm{Ag}_{x}\right)_{2}$ is attractive because the ground state is downward convex. These calculated results suggest that the solid solution of $\operatorname{Mg}\left(\mathrm{Zn}_{1-x} \mathrm{Ag}_{x}\right)_{2}$ is stable, which is consistent with the experimental results. ${ }^{26)}$ As shown in Fig. 6(b) and (c), Zn-Ca and $\mathrm{Zn}-\mathrm{Zr}$ also involve attractive interactions. However, because of the instability of the $\mathrm{MgCa}_{2}$ and $\mathrm{MgZr}_{2}$ Laves phases, the formation enthalpy of $\operatorname{Mg}\left(\mathrm{Zn}_{1-x} \mathrm{Ca}_{x}\right)_{2}$ and $\operatorname{Mg}\left(\mathrm{Zn}_{1-x} \mathrm{Zr}_{x}\right)_{2}$ increases monotonically with increasing $\mathrm{Ca}$ and $\mathrm{Zr}$ content. These results suggest that the solid solutions of $\mathrm{Mg}\left(\mathrm{Zn}_{1-x} \mathrm{Ca}_{x}\right)_{2}$ and $\operatorname{Mg}\left(\mathrm{Zn}_{1-x} \mathrm{Zr}_{x}\right)_{2}$ are unstable. The result for $\mathrm{Mg}\left(\mathrm{Zn}_{1-x} \mathrm{Ca}_{x}\right)_{2}$ is consistent with the experimental ones; ${ }^{28)}$ therefore, our

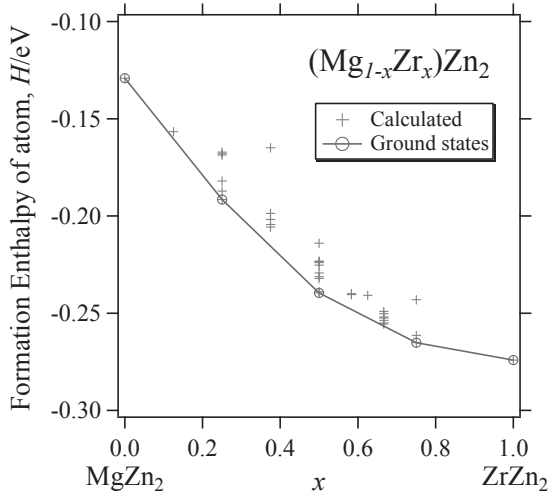

Fig. 7 Calculated formation enthalpies of $\left(\mathrm{Mg}_{1-x} \mathrm{Zr}_{x}\right) \mathrm{Zn}_{2}$.

calculation correctly describes the solid solution state of the Laves phase containing $\mathrm{Ag}$ and $\mathrm{Ca}$.

In case of $\mathrm{Zr}$ substitution, there is another experimental result. Ren et al. reported that $\mathrm{Zr}$ is located at the $4 \mathrm{f}$ site and forms $\left(\mathrm{Mg}_{1-x} \mathrm{Zr}_{x}\right) \mathrm{Zn}_{2}{ }^{29)}$ Figure 7 shows the calculated formation enthalpies of $\left(\mathrm{Mg}_{1-x} \mathrm{Zr}_{x}\right) \mathrm{Zn}_{2}$. The interaction between $\mathrm{Mg}$ and $\mathrm{Zr}$ on the $\mathrm{Mg}$ sublattice is attractive, and the formation enthalpy decreases monotonically with increasing $\mathrm{Zr}$ content. Therefore, our calculations suggest that $\mathrm{Zr}$ tends to be located at the $4 \mathrm{f}$ site in terms of the energy of the ground state.

The calculated result for the system with added $\mathrm{Zr}$ apparently indicates the formation of $\left(\mathrm{Mg}_{1-x} \mathrm{Zr}_{x}\right) \mathrm{Zn}_{2}$, which is supported by the experimental results reported in Ref. 29). Reference 3) concluded that $\mathrm{Mg}-2.4 \mathrm{Zn}-0.1 \mathrm{Ag}-0.1 \mathrm{Ca}-$ $0.16 \mathrm{Zr}$ (ZKQX) obtained by homogenization and hot extrusion has fine precipitates. We should discuss the relationship between the obtained formation enthalpy and the size of the precipitates. The growth of precipitates is generally considered in terms of Ostwald ripening. ${ }^{30)}$ More large precipitates grow and small precipitates disappear owing to the flow of solute atoms from small to large precipitates, which is because of the differences in the solute concentration at the interface according to the radius of the precipitates. In this theory, the size of the precipitates is described by,

$$
r^{3}-r_{0}^{3}=K t, \quad K \propto \sigma D X_{e},
$$

where, $r$ and $r_{0}$ are the average radii at $t$ and $t=0$, respectively. $D$ is the diffusion constant, $\sigma$ is the interfacial energy, and $X_{\mathrm{e}}$ is the equilibrium concentration of the solute 
in the parent phase for precipitates with infinite radius, which is the solubility limit in the equilibrium phase diagram. From this equation, when $\sigma, D$, and $X_{\mathrm{e}}$ are small, grains grow slowly, and the precipitates remain small. To keep $X_{\mathrm{e}}$ small, the formation enthalpy of the precipitates should be low, which is trivial from the common tangential line between the parent phase and precipitation phase. Therefore, the experimental result, in which fine precipitates were formed in $\mathrm{ZKQX}$, seems to indicate that the introduced $\mathrm{Zr}$ is located at the $\mathrm{Mg}$ site even in terms of the size of the precipitates. We note that our calculation may not indicate the stability of materials at finite temperatures owing to the limitations of the calculation techniques. To obtain a definitive result, it is necessary to include the effect of the finite temperature, for example, using the cluster variation method. In any case, data obtained by systematic calculations on the formation energy of the Laves phase are useful for controlling the precipitation of the Laves phase at a desired size.

\section{Conclusions}

To investigate the stability and mechanical properties of various Mg-based Laves phases, we performed firstprinciples calculation of the formation enthalpy and phonon dispersion. The formation enthalpy and phonon dispersion results indicated that $\mathrm{MgX}_{2}(\mathrm{X}=\mathrm{Al}, \mathrm{Co}, \mathrm{Ni}, \mathrm{Cu}, \mathrm{Zn})$ and $\mathrm{Mg}_{2} \mathrm{X}(\mathrm{X}=\mathrm{Ca}, \mathrm{Sr}, \mathrm{Y}, \mathrm{Ba})$ have statically and dynamically stable structures, which is consistent with the experimental results. Furthermore, comparison with the experimental results indicates that $\mathrm{MgAl}_{2}$ and $\mathrm{Mg}_{2} \mathrm{La}$ are metastable phases of the $\mathrm{Mg}-\mathrm{Al}$ and $\mathrm{Mg}-\mathrm{La}$ systems, respectively. Using the CEM combined with DFT, we described the thermodynamic stability of the solid solution Laves phase. Our theoretical investigation suggests that attractive interaction contributes to the concentration of the additional element $(\mathrm{Ag}, \mathrm{Ca}$, or $\mathrm{Zr})$ in the $\mathrm{MgZn}_{2}$ Laves phase.

\section{Acknowledgments}

This work was supported by the JST's Advanced Low Carbon Technology Research and Development Program (ALCA). The authors gratefully acknowledge Dr. Hono, Dr. Sasaki, and Prof. Nakamura for valuable discussions.

\section{REFERENCES}

1) J.F. Nie: Metall. Mater. Trans. A 43 (2012) 3891-3939.

2) C.L. Mendis, K. Oh-ishi, Y. Kawamura, T. Honma, S. Kamado and K. Hono: Acta Mater. 57 (2009) 749-760.

3) K. Oh-ishi, C.L. Mendis, T. Homma, S. Kamado, T. Ohkubo and K. Hono: Acta Mater. 57 (2009) 5593-5604.

4) A. Issa, J.E. Saal and C. Wolverton: Acta Mater. 65 (2014) 240-250.

5) S. Iikubo, S. Hamamoto and H. Ohtani: Mater. Trans. 54 (2013) 636640.

6) T. Tokunaga, H. Kominato, S. Iikubo and H. Ohtani: Mater. Trans. 54 (2013) 647-655.

7) R. Masumoto, H. Ohtani and M. Hasebe: J. Japan Inst. Metals 73 (2009) 683-690.

8) G. Kresse and J. Furthmüller: Phys. Rev. B 54 (1996) 11169-11186.

9) G. Kresse and J. Furthmüller: Comput. Mater. Sci. 6 (1996) 15-50.

10) P.E. Blöchl: Phys. Rev. B 50 (1994) 17953-17979.

11) G. Kresse and D. Joubert: Phys. Rev. B 59 (1999) 1758-1775.

12) J.P. Perdew, K. Burke and M. Ernzerhof: Phys. Rev. Lett. 77 (1996) 3865-3868.

13) J.P. Perdew, K. Burke and M. Ernzerhof: Phys. Rev. Lett. 78 (1997) 1396.

14) A. van de Walle, M. Asta and G. Ceder: Calphad 26 (2002) 539-553.

15) G. Kresse, J. Furthmüller and J. Hafner: Europhys. Lett. 32 (1995) 729.

16) K. Parlinski, Z.Q. Li and Y. Kawazoe: Phys. Rev. Lett. 78 (1997) 40634066.

17) A. Togo and I. Tanaka: Scr. Mater. 108 (2015) 1-5.

18) P. Villars and K. Cenzual: Pearson's Crystal Data: Crystal Structure Database for Inorganic Compounds (on DVD), Release 2015/16, (ASM International $^{\circledR}$, Materials Park, Ohio, USA).

19) Y. Xu, M. Yamazaki and P. Villars: Jpn. J. Appl. Phys. 50 (2011) $11 \mathrm{RH} 02$.

20) H. Okamoto: J. Phase Equilib. Diff. 29 (2008) 208-209.

21) H. Okamoto: J. Phase Equilib. Diff. 28 (2007) 305-306.

22) R.L. Berry and G.V. Raynor: Acta Cryst. 6 (1953) 178-186.

23) Y. Komura: Acta Cryst. 15 (1962) 770-778.

24) T. Rajasekharan, D. Akhtar, R. Gopalan and K. Muraleedharan: Nature 322 (1986) 528-530.

25) Y.B. Kang, L. Jin, P. Chartrand, A.E. Gheribi, K. Bai and P. Wu: Calphad 38 (2012) 100-116.

26) J. Wang, Y.N. Zhang, P. Hudon, I.H. Jung, M. Medraj and P. Chartrand: J. Alloys Compd. 639 (2015) 593-601.

27) T. Bhattacharjee, C.L. Mendis, T.T. Sasaki, T. Ohkubo and K. Hono: Scr. Mater. 67 (2012) 967-970.

28) Y.N. Zhang, D. Kevorkov, F. Bridier and M. Medraj: Sci. Technol. Adv. Mater. 12 (2011) 025003.

29) Y.P. Ren, Y. Guo, D. Chen, S. Li, W.L. Pei and G.W. Qin: Calphad 35 (2011) 411-415.

30) S. Takaki and K. Tsuzaki: Zairyo-soshikigaku, (Asakura-shoten, 2000) pp. 112-116 (in Japanese). 